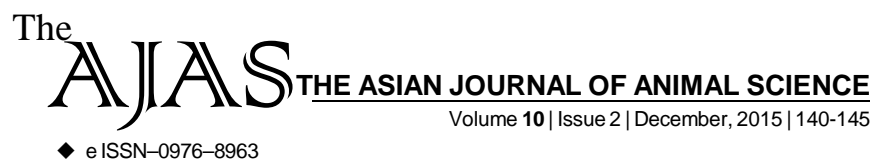

DOI : 10.15740/HAS/TAJAS/10.2/140-145 Visit us | www.researchjournal.co.in $\mathrm{S}$

RESEARCH ARTICLE.

\title{
Effect of feeding of urea ammoniated soybean straw on blood biochemical parameters of lactating cows
}

\author{
R.R. SHELKE, S.D. CHAVAN, S.P. WAGHMARE AND P.A. KAHATE
}

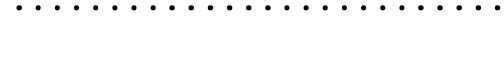

Author for Corresponding -

\section{R.R. SHELKE}

Department of Animal

Husbandry and Dairy Science,

College of Agriculture, Dr.

Panjabrao Deshmukh Krishi

Vidyapeeth, AKOLA (M.S.) INDIA

Email: rrspkv@gmail.com

See end of the article for

Coopted authors'
ABSTRACT...... Feeding of untreated soybean straw $\left(\mathrm{T}_{2}\right)$ and 2 per cent urea treated soybean straw $\left(\mathrm{T}_{3}\right)$ was evaluated on the performance of lactating cows in reference to conventional jowar straw diet $\left(\mathrm{T}_{1}\right)$. It was found within 120 days trial that, the Hb levels showed a increase from the initial level of 9.83 to $9.96,9.76$ to 10.08 and 9.86 to $10.80 \mathrm{~g} / \mathrm{dl} / \mathrm{cow}$, blood glucose levels increased from 48.68 to $48.89,45.89$ to 53.36 and 45.16 to $56.24 \mathrm{mg} / \mathrm{dl}$ in $\mathrm{T}_{1}, \mathrm{~T}_{2}$ and $\mathrm{T}_{3}$ groups, respectively The STP levels increase from initial content was 5.89 to $6.05,5.76$ to 6.38 and 5.70 to $6.58 \mathrm{~g} / \mathrm{dl}$, Significantly more BUN $(17.82 \mathrm{mg} / \mathrm{dl})$ was noticed in cows offered with $\mathrm{T}_{3}$ followed by $\mathrm{T}_{2}(13.85 \mathrm{mg} / \mathrm{dl})$ and $\mathrm{T}_{2}(16.66 \mathrm{mg} / \mathrm{dl})$ while blood urea pooled means were noticed as $29.65,38.13$ and $35.67 \mathrm{mg} / \mathrm{dl}$ in cows offered $\mathrm{T}_{1}, \mathrm{~T}_{2}$ and $\mathrm{T}_{3}$ groups, respectively The pooled means of STL were 278.15, 298.22 and $302.30 \mathrm{mg} / \mathrm{d}$, the pooled means of STC content were $69.18,68.64$ and $77.06 \mathrm{mg} / \mathrm{dl}$ and the serum triglyceride content of blood increased were $16.72,16.79$ and $17.57 \mathrm{mg} / \mathrm{dl}$, in cows offered $\mathrm{T}_{1}, \mathrm{~T}_{2}$ and $\mathrm{T}_{3}$ groups, respectively. The results do suggest that 2 per cent urea treated SBS can find a place in the ration of lactating cows without any adverse effect on health of cows.

KEY WORDS...... Conventional jowar straw, Untreated soybean straw, 2 per cent urea treated soybean straw, Blood metabolic profile, Haemoglobin $(\mathrm{Hb})$, Blood glucose, Serum total protein (STP), Blood urea nitrogen (BUN), Blood urea, Serum total lipids (STL)/ cholesterol/ triglyceride)

HOW TO CITE THIS ARTICLE - Shelke, R.R., Chavan, S.D., Waghmare, S.P. and Kahate, P.A. (2015) Effect of feeding of urea ammoniated soybean straw on blood biochemical parameters of lactating cows. Asian J. Animal Sci., 10(2): 140-145.

ARTICLE CHRONICLE - Received : 30.06.2015; Revised : 06.11.2015; Accepted : 10.11.2015 